\title{
Characterization of Modified Crumb Rubber Concrete
}

\author{
Adeyemi Oluwaseun Adeboje ${ }^{1 *}$, Williams Kehinde Kupolati ${ }^{1}$, Emmanuel Rotimi Sadiku $^{2}$, Julius Musyoka Ndambuki ${ }^{1}$ \\ ${ }^{1}$ Department of Civil Engineering, Tshwane University of Technology, Pretoria 0001, South Africa \\ ${ }^{2}$ Department of Chemical, Metallurgical \& Materials Engineering, Tshwane University of Technology, Pretoria 0001, South \\ Africa
}

Corresponding Author Email: AdebojeAO@tut.ac.za

https://doi.org/10.18280/ijsdp.150315

Received: 9 December 2018

Accepted: 14 December 2019

\section{Keywords:}

concrete, crumb rubber, mechanical properties, microstructure, walkways

\begin{abstract}
Concrete is a very important construction material used worldwide for the construction of bridges, buildings, dams, kerbs, patios, pools, roads, walkways and other civil engineering structures. The constituents of concrete are cement, coarse aggregate, fine aggregate and water. Efforts were made in this work to evaluate the suitability of crumb rubber as a partial substitute of sand in concrete mixes. This research evaluated the effects of partial substitution of sand with crumb rubber on the mechanical properties and microstructural formation of modified crumb rubber concrete. The control concrete sample and concrete samples with 1, 2, 3 and 4\% sand content in the concrete substituted with crumb rubber were cured for 3, 7, 28, 90 and 120 days, respectively, and then tested. The laboratory experiments conducted on the concrete samples were workability, bulk density, compressive strength, tensile splitting strength, scanning electron microscopy (SEM) and energy dispersive spectroscopy (EDS). Improvement in the strength and densification of the microstructure of the concrete samples occurred as the curing age increased from 3 to 7, 28, 90 and 120 days, respectively. This research further showed that marginal improvement in both the strength properties and microstructural formation of the modified crumb rubber concrete can be achieved by substituting $1 \%$ sand with crumb rubber.
\end{abstract}

\section{INTRODUCTION}

Waste materials, such as crumb rubber, are yet to be fully utilized for concrete works, other construction purposes or industrial applications, especially in many African countries [1]. Adequate evaluation of the crumb rubber (granulated form of waste rubber tyres) is required before it (crumb rubber) can be recommended as a material to partially replace sand in concrete [2-4].

Owing to its wide usage across the world, about 12 billion tonnes of concrete is consumed globally, on an annual basis. The rise in temperature of the earth is called global warming. Carbon dioxide $\left(\mathrm{CO}_{2}\right)$ is one of the greenhouse gases and its huge quantities is emitted in the production of cement and concrete. This leads to degradation of the ozone layer of the earth and causes global warming. It thus calls for concern to arrest the situation [2, 3].

Energy used up in the construction industry is about $30 \%$ of the total energy consumed from all human activities. Hence, it looks promising to utilize other less thermal conductive materials for construction to achieve efficient operational energy in the production of concrete [3]. The mechanical properties and microstructural formation of fine and coarse aggregates are extremely important features to achieve thermal insulation of concrete; hence, utilization of air entrainments and thermal non-conductive aggregates can enhance concrete's thermal resistance [3].

Human activities have been on the increase because the global population is constantly increasing [5] and this has resulted in astronomical increment in the volume of waste generated from activities of man. As a result, the total number of vehicles has also increased globally [6, 7]. The astronomic increase in the number of vehicles used worldwide gave rise to an increase in the quantities of waste rubber tyres used and dumped in the environment $[8,9]$.

It is important to ensure that the waste tyres are efficiently disposed at incinerators, landfills and other means of disposing the waste tyres have proved inefficient, owing to the nondegradable nature of the waste tyre rubber $[10,11]$. Disposal of waste tyres on landfills has also led to provision of houses for pests, reptiles and rodents. These insects and reptiles are venomous, they attack human beings and domestic pets, destroy the environment and are deadly to human and destroy ecological balance in the environment $[12,13]$.

Crumb rubber is produced from waste tyre rubbers. The metal strings in the waste rubbers are removed and the waste rubbers are torn and ground into desired grain sizes [14-17]. Recent advances have ventured on the evaluation of crumb rubber to determine its suitability as a replacement for fine and coarse aggregates for concrete production. Literature has also shown that replacement of sand with crumb rubber reduces the strength properties of concrete [18-21].

This research was an experimental study conducted the applicability of waste crumb rubber as a partial replacement for sand in concrete. This work investigated the effects and suitability of partially substituting sand with crumb on the mechanical properties and microstructural formation of modified crumb rubber concrete. 


\section{MATERIALS AND METHODS}

The materials used and methods adopted for the evaluation of strength properties and microstructural formation of the control concrete sample and the modified crumb rubber concrete samples $(1,2,3$ and $4 \%$ sand substituted with crumb rubber) are discussed in this section.

\subsection{Materials}

Cement, sand, granite, crumb rubber and water were the materials used for concrete production. The materials are discussed as follows:

\subsubsection{Cement}

Sephaku 32 CEM IV/B (V) $32.5 \mathrm{~N}$ conforming to ref. [22] and having specific gravity (SG) of 2.48 was used for the study. Cement sample is presented in Figure 1a.

\subsubsection{Sand}

River sand having maximum size of $4.75 \mathrm{~mm}$ was used for the study. Sand sample is presented in Figure $1 \mathrm{~b}$.

\subsubsection{Granite}

Granite sample having maximum size of $19 \mathrm{~mm}$ was used for the study. Granite sample is presented in Figure 1c. Aggregates used were donated by Raumix Aggregates, Centurion, Pretoria, South Africa.

\subsubsection{Crumb rubber}

Crumb rubber having specific gravity (SG) of 1.14, donated by TOSAS recycling plant, Gemiston, Gauteng Province, South Africa was used for the study. Crumb rubber sample is presented in Figure 1d.

\subsubsection{Water}

Potable water obtained from the Civil Engineering laboratory of Tshwane University of Technology, Pretoria, South Africa was used for the study. Water sample is presented in Figure 1e.

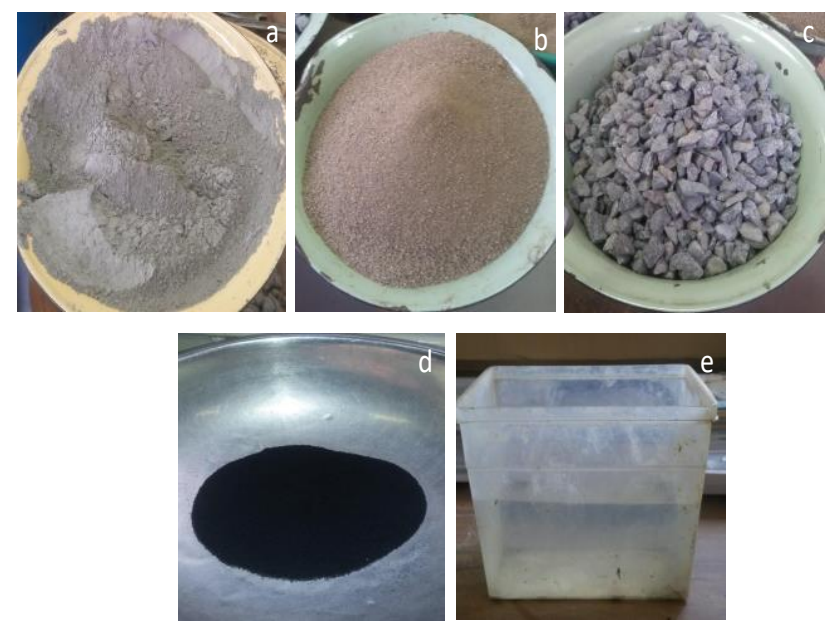

Figure 1. Samples of (a) cement, (b) sand, (c) granite, (d) crumb; and (e) water used for concrete

\subsection{Methods}

Experimental investigations were carried out to evaluate the mechanical properties and microstructural formation of the control sample and the concrete samples with 1, 2, 3 and 4\% sand substituted with crumb rubber. The laboratory tests conducted were slump, bulk density, compressive strength, tensile splitting strength, scanning electron microscopy (SEM) and energy dispersive spectroscopy (EDS).

\subsubsection{Slump}

The workability of fresh concrete was determined by obtaining the reduction or subsidence in the height of concrete with the aid of slump test. Concrete cylinders having top diameter of $100 \mathrm{~mm}$, base diameter of $300 \mathrm{~mm}$ and height of $200 \mathrm{~mm}$ in line with specification [23] were used.

\subsubsection{Bulk density}

The bulk density of hardened concrete was carried out by weighing $150 \times 150 \times 150 \mathrm{~mm}$ concrete cubes at different curing ages with the aid of electronic weighing balance in conformity to specification [24].

\subsubsection{Compressive strength}

The compressive strength of hardened concrete was carried out to determine the maximum load required to crush $150 \mathrm{x}$ $150 \times 150 \mathrm{~mm}$ concrete cubes with the aid of compression testing machine in conformity to specification [25]

\subsubsection{Tensile splitting strength}

The tensile splitting strength of hardened concrete was carried out to determine the indirect tensile load required to crush concrete cylinders having diameter of $150 \mathrm{~mm}$ and height of $300 \mathrm{~mm}$ in conformity to specification [26].

\subsubsection{Scanning electron microscopy}

The microstructural formation of the control sample and the concrete samples with $1,2,3$ and $4 \%$ sand substituted with crumb rubber was determined using the scanning electron microscope (SEM). About $15 \mathrm{~mm}$ long and $5 \mathrm{~mm}$ thick specimen was cut from the central portion of the concrete cubes for the SEM analysis.

\subsubsection{Energy dispersive spectroscopy}

The elemental composition of the control sample and the concrete samples with 1, 2, 3 and $4 \%$ sand substituted with crumb rubber was determined using the energy dispersive spectroscope (EDS). The collection of sample was similar to that of SEM.

\subsection{Concrete mix design and preparation}

\subsubsection{Mix design}

Control concrete sample and concrete samples with 1, 2, 3 and $4 \%$ sand substituted with crumb rubber are represented with samples $B_{0}, B_{1}, B_{2}, B_{3}$ and $B_{4}$ respectively. The mix proportion for $25 \mathrm{MPa}$ concrete samples prepared in line with specifications $[27,28]$ is presented in Table 1 .

\subsubsection{Concrete preparation}

Different concrete samples $\left(\mathrm{B}_{0}, \mathrm{~B}_{1}, \mathrm{~B}_{2}, \mathrm{~B}_{3}\right.$ and $\left.\mathrm{B}_{4}\right)$ used for the study were prepared with the electronic concrete mixer in conformity to specifications [27]. Loss of concrete portion (part) was prevented during mixing. Homogeneity of the different concrete mixes was carefully maintained. Testing of the different concrete cubes for compressive strength and cylinders for tensile splitting strength was done at curing ages of 3, 7, 28, 90 and 120 days, respectively. 
Table 1. Mix proportioning for the partial substitution of sand with crumb rubber in concrete

\begin{tabular}{cccccc}
\hline \multirow{2}{*}{ Materials } & \multicolumn{5}{c}{ Proportions of Crumb rubber Substituted } \\
\cline { 2 - 6 } & Control & $1 \%$ crumb rubber & 2\% crumb rubber & $3 \%$ crumb rubber & $4 \%$ crumb rubber \\
\hline Cement $(\mathrm{gm})$ & 4410 & 4410 & 4410 & 4410 & 4410 \\
Sand $(\mathrm{gm})$ & 7973 & 7893.3 & 7813.5 & 7733.8 & 7654.1 \\
Granite $(\mathrm{gm})$ & 12201 & 12201 & 12201 & 12201 & 12201 \\
Water $(\mathrm{ml})$ & 2416 & 2416 & 2416 & 2416 & 2416 \\
Crumb rubber $(\mathrm{gm})$ & 0 & 79.7 & 159.5 & 239.2 & 318.9 \\
\hline
\end{tabular}

\section{RESULTS AND DISCUSSION}

This section elaborates on the results of the experimental setup presented in section 2 .

\subsection{Influence of partial replacement of sand with crumb rubber on the slump of concrete}

The results of the slump test for the control sample and the concrete samples with $1,2,3$ and $4 \%$ sand substituted with crumb rubber was $45,40,35,30$ and $30 \mathrm{~mm}$ respectively, as presented in Figure 2. There was reduction in the slump value of the concrete sample upon substitution of 1,2 and $3 \%$ sand with crumb rubber but the slump values remained $30 \mathrm{~mm}$ with the substitution of $4 \%$ sand with crumb rubber. Crumb rubber drew water from the concrete because it had affinity for water. Though substitution of sand with crumb rubber caused decrease in the concrete slump, however, the concrete samples remained workable. The modified crumb rubber concrete had slump values, between 30 and $40 \mathrm{~mm}$, which complied with recommendation for concrete which has stone sample with maximum size of $19 \mathrm{~mm}$ and was vibrated moderately to range from 25 to $100 \mathrm{~mm}$ by literature [28]. The results obtained compares favourably with that obtained by Batayneh [18] which show that increase in the quantity of sand substituted with crumb rubber in the concrete mixes from the $0 \%$ (control sample) to $20,40,60,80$ and $100 \%$ reduced the slump from 75 to $61,36,1810$ and $5 \mathrm{~mm}$, respectively. Nevertheless, the workability or slump of the modified crumb rubber concrete mixes was not affected or compromised.

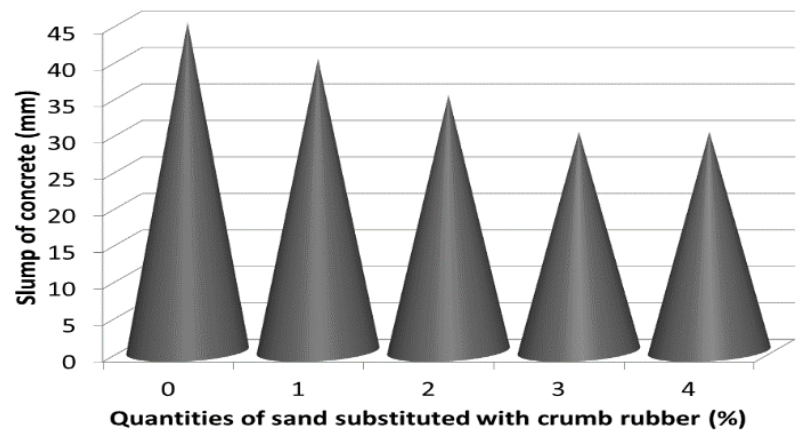

Figure 2. Slump of concrete samples with sand substituted with crumb rubber

\subsection{Influence of partial replacement of sand with crumb rubber on the bulk density of concrete}

The results of the bulk densities of the control concrete sample and the concrete samples with 1,2, 3 and 4\% sand substituted with crumb rubber is presented in Figure 3. The control concrete sample and $1 \%$ sand substituted with crumb rubber had the same bulk density value $\left(2320 \mathrm{~kg} / \mathrm{m}^{3}\right)$ at 3 and 7 days curing. Concrete sample with $2 \%$ sand substituted with crumb rubber had bulk density value of $2310 \mathrm{~kg} / \mathrm{m}^{3}$ when cured for 3 and 7 days. Concrete samples with 3 and 4\% sand substituted with crumb rubber had the same bulk density value $\left(2300 \mathrm{~kg} / \mathrm{m}^{3}\right)$ at 3 and 7 days curing. It can be observed that slight reduction occurred in the bulk density of the concrete samples at 3 and 7 days curing with increase in the quantity of sand substituted with crumb rubber. The values of the bulk densities of the control concrete sample and concrete samples with $1,2,3$ and $4 \%$ sand substituted with crumb rubber at 28 days curing were 2330, 2320, 2310, 2300 and $2300 \mathrm{~kg} / \mathrm{m}^{3}$ respectively.

The control concrete sample had bulk density of 2330 and $2340 \mathrm{~kg} / \mathrm{m}^{3}$ at 90 and 120 days curing respectively. However, concrete samples with $1,2,3$ and $4 \%$ sand substituted with crumb rubber had bulk densities of 2330, 2320, 2310 and 2310 respectively at both 90 and 120 days curing. There was minimal reduction in the values of the bulk density of the different modified crumb rubber concrete samples as the crumb rubber content increased. Finally, the bulk density results obtained in this study for the control concrete sample and the concrete samples with 1,2,3 and 4\% sand substituted with crumb rubber were within specified limits, as all the results ranged between 2300 and $2340 \mathrm{~kg} / \mathrm{m}^{3}$ which fell within the specified range of between 2001 and $2600 \mathrm{~kg} / \mathrm{m}^{3}$ specified by EN $12390-7$ [24].

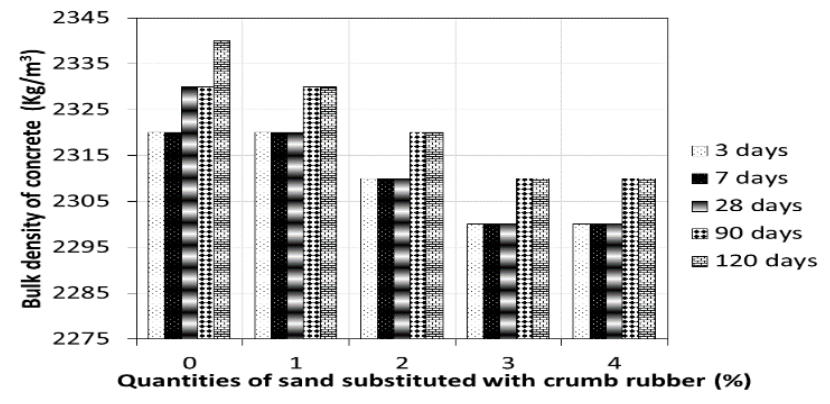

Figure 3. Bulk density of concrete samples with sand partially substituted with crumb rubber

\subsection{Influence of partial replacement of sand with crumb rubber on the compressive strength of concrete}

Results of the compressive strength of the control concrete sample and the concrete samples with 1, 2, 3 and 4\% sand substituted with crumb rubber is presented in Figure 4 . The values of the compressive strength of sample $\mathrm{B}_{0}$ was $16.0,18.5$ 27.0, 36.5 and $37.5 \mathrm{MPa}$ while those of sample $\mathrm{B}_{1}$ were 18.5 , $21.0,28.5,41.0$ and $42.5 \mathrm{MPa}$ at 3, 7, 28, 90 and 120 days of curing, respectively. The compressive strength of the concrete improved from the control concrete sample to the concrete 
sample with $1 \%$ sand substituted with crumb rubber. Conversely, the compressive strength of the concrete samples reduced progressively from samples $B_{1}$ to $B_{2}$, from sample $B_{2}$ to $\mathrm{B}_{3}$ and from sample $\mathrm{B}_{3}$ to $\mathrm{B}_{4}$. The values of the compressive strength of concrete samples with $2 \%$ sand substituted with crumb rubber (sample $\mathrm{B}_{2}$ ) was 16.0, 19.0, 25.0, 37.0 and 39.0 $\mathrm{MPa}$, the compressive strength of concrete samples with $3 \%$ sand substituted with crumb rubber (sample $\mathrm{B}_{3}$ ) was 14.0, 18.5, 23.0, 35.0 and $36.5 \mathrm{MPa}$; and the compressive strength of the concrete samples with $4 \%$ sand substituted with crumb rubber (sample $\mathrm{B}_{4}$ ) was 12.0, 18.0, 21.5, 32.0 and 34.5 at 3, 7, 28, 90 and 120 days curing, respectively.

At 28 days curing, the compressive strength of the concrete samples showed $5.6 \%$ improvement (from sample $\mathrm{B}_{0}$ to $\mathrm{B}_{1}$ ) with the substitution of $1 \%$ sand with crumb rubber, $7.4 \%$ reduction (from sample $B_{1}$ to $B_{2}$ ) with the $2 \%$ substitution of sand with crumb rubber, $14.8 \%$ reduction (from sample $\mathrm{B}_{2}$ to $\mathrm{B}_{3}$ ) with the substitution of $3 \%$ sand with crumb rubber and $20.4 \%$ reduction (from sample $B_{3}$ to $B_{4}$ ) with the substitution of $4 \%$ sand with crumb rubber. The distinction between this work and related literature is the improvement in the compressive strength between the control concrete sample and the sample with substitution of $1 \%$ sand substituted with crumb rubber. This development shows that crumb rubber can be used as a supplementary construction material in place of sand to improve the compressive strength of concrete. This advance differentiates this work from existing literature [19, $21,29]$ which showed drastic reduction in the compressive strength of concrete with the increase in quantity of sand replaced with crumb rubber. This distinction or contrast can be attributed to the quantities of sand substituted with crumb rubber. The existing literature used variation of $5 \%$ while this work utilized variation of $1 \%$. The very small proportion examined in previous work was not considered [19, 21, 29] in the existing literature.

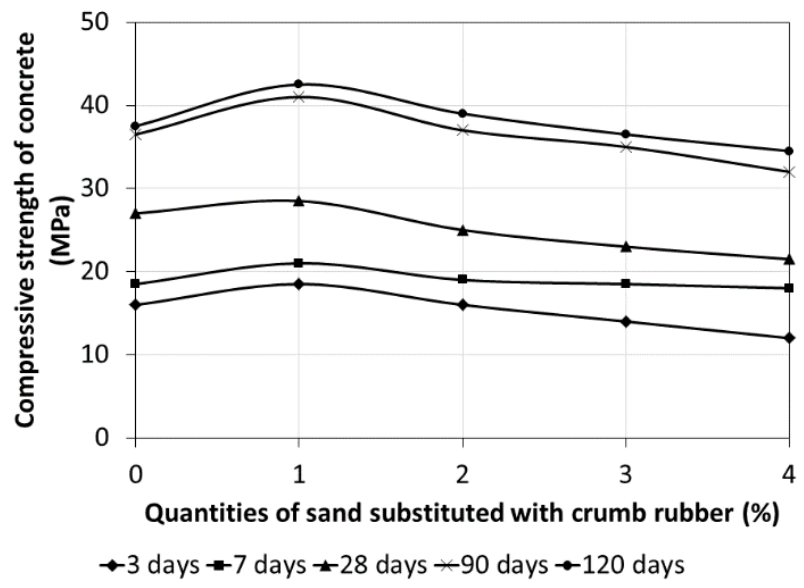

Figure 4. Compressive strength of concrete with sand partially substituted with crumb rubber

Furthermore, this study established that the modified crumb rubber concrete possessed substantial early strength at 3 days of curing, which could be attributed to fly ash composition of the Sephaku 32.5 cement used. However, there was slight improvement in the strength of concrete from 3 to 7 days curing. Great improvement in the compressive strength of the modified crumb rubber concrete was also obtained between 7 and 28 days curing and from 28 to 90 days curing. There was however a slight and unnoticeable improvement in the compressive strength of the concrete between 90 and 120 days, which is suggestive of nearing the peak of the compressive strength of the concrete at 120 days curing. Conclusively, there was improvement in all the concrete samples as the age of curing increased as suggested by literature [30]. However, Adeboje et al. [31] gave a prelude to the increment or improvement in the compressive strength of concrete with the joint substitution of $0.5 \%$ cement with bentonite clay and $0.5 \%$ sand with crumb rubber.

\subsection{Influence of partial replacement of sand with crumb rubber on the tensile splitting strength of concrete}

The result of the tensile splitting strength of the control concrete sample and the concrete samples with 1, 2, 3 and 4\% sand substituted with crumb rubber is presented in Figure 5. The control concrete sample (sample $\mathrm{B}_{0}$ ) had tensile splitting strength of 1.60, 1.90, 2.65, 3.70 and 3.75 $\mathrm{MPa}$ at 3, 7, 28, 90 and 120 days curing. Sample $B_{1}(1 \%$ sand substituted with crumb rubber) had tensile splitting strength of $1.85,2.10,2.80$, 4.15 and $4.30 \mathrm{MPa}$ while sample $\mathrm{B}_{2}$ had tensile splitting strength of $1.55,1.90,2.50,3.65$ and $3.90 \mathrm{MPa}$ at $3,7,28,90$ and 120 days of curing respectively. Sample $\mathrm{B}_{3}$ (3\% sand substituted with crumb rubber) had tensile splitting strength of $1.35,1.85,2.35,3.50$ and $3.65 \mathrm{MPa}$ while sample $\mathrm{B}_{4}(4 \%$ sand substituted with crumb rubber) had tensile splitting strength of $1.20,1.85,2.20,3.20$ and $3.45 \mathrm{MPa}$ at $3,7,28,90$ and 120 days of curing respectively.

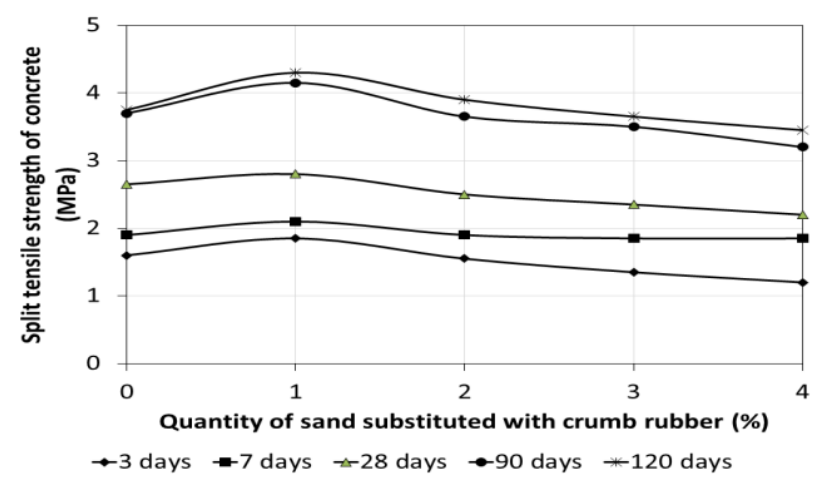

Figure 5. Tensile splitting strength of concrete with sand partially substituted with crumb rubber

The tensile splitting strength result at 28 days curing shows $5.7 \%$ improvement (from sample $\mathrm{B}_{0}$ to $\mathrm{B}_{1}$ ) with the substitution of $1 \%$ sand with crumb rubber, $5.7 \%$ reduction (from sample $B_{1}$ to $B_{2}$ ) with the substitution of $2 \%$ sand with crumb rubber, $11.3 \%$ reduction (from $\mathrm{B}_{2}$ to $\mathrm{B}_{3}$ ) with the substitution of $3 \%$ sand with crumb rubber and $17 \%$ reduction (from $\mathrm{B}_{3}$ to $\mathrm{B}_{4}$ ) with the substitution of $4 \%$ sand with crumb rubber. Similar to the compressive strength result, the tensile splitting strength of the concrete improved with substitution of $1 \%$ sand with crumb rubber. The tensile splitting strength however reduce with further substitution of 2, 3 and $4 \%$ sand with crumb rubber at curing ages $3,7,28,90$ and 120 days respectively. This work contrasts the result reported in by ElGammal et al. [19], Aravind et al. [21], Akinyele et al. [29], which showed drastic reduction in the tensile strength of concrete without any evidence of achieving improvement in the strength properties of concrete. However, improvement in the tensile splitting strength of concrete with the joint 
substitution of $0.5 \%$ cement with bentonite clay and $0.5 \%$ sand with crumb rubber was recently documented by Adeboje et al. [31].

\subsection{Influence of partial replacement of sand with crumb rubber on the microstructure of concrete}

The morphology of the control concrete sample and the concrete samples with $1,2,3$ and $4 \%$ sand substituted with crumb rubber (samples $\mathrm{B}_{0}, \mathrm{~B}_{1}, \mathrm{~B}_{2}, \mathrm{~B}_{3}$ and $\mathrm{B}_{4}$ ) is presented in Figure $6 \mathrm{a}, \mathrm{b}, \mathrm{c}, \mathrm{d}$ and e, respectively. The denser or closelypacked the microstructure of the concrete sample, the more improved the mechanical properties and the strength properties of the concrete. Sample $\mathrm{B}_{0}$ (Figure 6a) looks dense but pores are visible on its micrograph which indicates that the voids need to be filled to attain a perfect and dense microstructure. Sample $B_{1}$ (Figure $6 b$ ) indicates a more compact and closely-packed microstructure compared to sample $\mathrm{B}_{0}$ (Figure 6a) which conformed to the improved strength discussed in sections 3.3 and 3.4. Conversely, the microstructural formation of the other concrete samples $\left(B_{2}\right.$, $\mathrm{B}_{3}$ and $\mathrm{B}_{4}$ ) became looser, less compact, less dense and weaker from sample $B_{2}$ (Figure $6 c$ ) to $B_{3}$ (Figure $6 d$ ) and from sample $\mathrm{B}_{3}$ (Figure $6 \mathrm{~d}$ ) to $\mathrm{B}_{4}$ Figure $6 \mathrm{e}$ ).
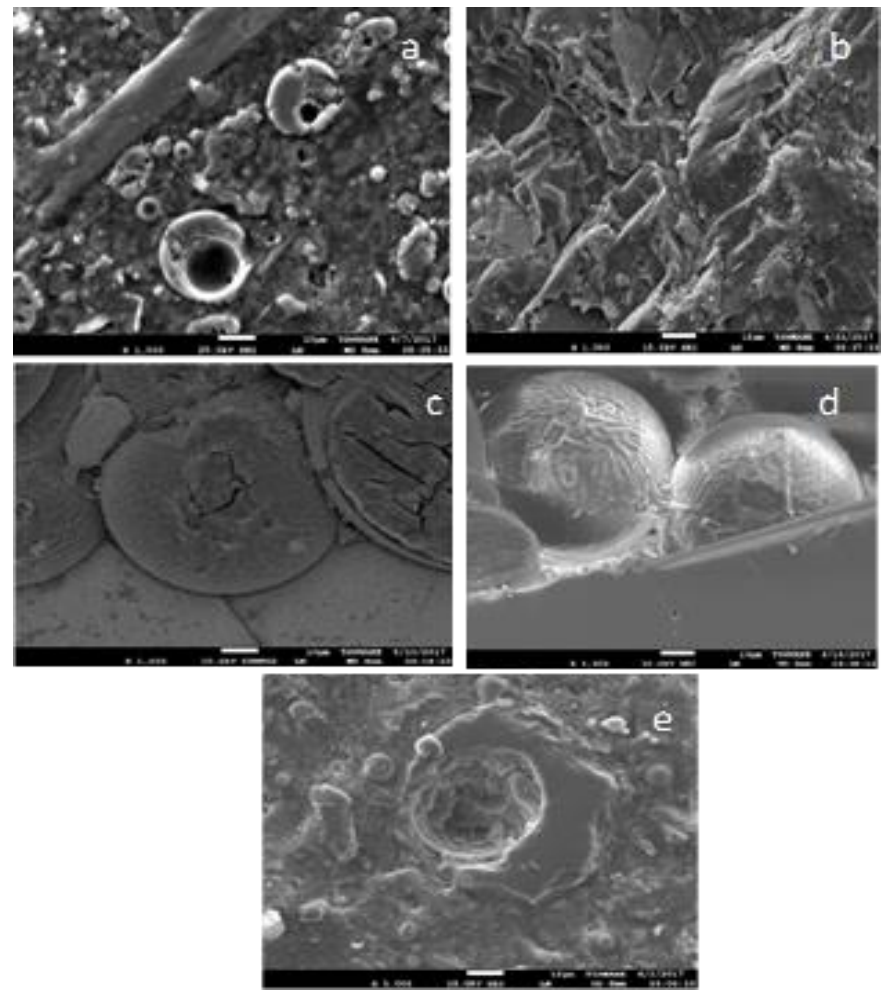

Figure 6. SEM micrographs for the Partial Substitution of sand with crumb rubber by (a) $0 \%$, (b) $1 \%$, (c) $2 \%$, (d) $3 \%$; and (e) $4 \%$ in concrete at 28 days

Therefore, the concrete sample became loose, less dense, less compact and that made the strength properties lesser and the concrete samples become weaker from sample $\mathrm{B}_{2}$ to $\mathrm{B}_{3}$ and from sample $B_{3}$ to $B_{4}$. Hence, the microstructural formation of concrete samples has direct impact on the strength parameters and mechanical properties of the modified crumb rubber concrete. This study suggests that substitution of sand with crumb rubber to achieve improved strength and microstructure should be limited to and not exceeding $1 \%$. This is because further substitution of sand with crumb rubber can lead to appearance of (or clustering of) crumb rubber around cement particles which can weaken the bond between cement and water, thus slowing down cement hydration and also mitigate against firm bonding between aggregates and cement paste. This phenomenon is similar to the situation where crumb rubber created voids in concrete which led to reduction in the strength of rubberized concrete [19, 29].

\subsection{Influence of partial replacement of sand with crumb rubber on the composition of concrete}

The EDS experiment gave the elemental composition for the control concrete sample and the concrete samples of 1,2 , 3 and $4 \%$ sand substituted with crumb rubber as presented in Table 2. Cement is the material which enhances hydration and strength development in concrete and also binds aggregates [32]. The major components of cement are oxides of calcium $(\mathrm{CaO})$, silicon $(\mathrm{SiO} 2)$, aluminium $\left(\mathrm{Al}_{2} \mathrm{O}_{3}\right)$ and iron $\left(\mathrm{Fe}_{2} \mathrm{O}_{3}\right)$ [32].

Oxygen plays important part in the microstructure of compounds [33] and strength improvement in concrete [34] which has abundant oxygen content. Similarly, compactness of the microstructure and strength improvement are also dependent on the abundance of oxygen in the concrete sample $[33,34]$. This work shows that concrete sample with $1 \%$ sand substituted with crumb rubber (sample $\mathrm{B}_{1}$ ) possessed the highest oxygen content ( $31.45 \%$ ) and also possessed high iron content $(48.62 \%)$ by weight. The abundance of both oxygen and iron enhanced improved strength improvement and the densest microstructure of the concrete sample (sample B1).

The amount of oxygen in the concrete samples after sample $\mathrm{B}_{1}$ is as follows: control concrete sample (sample $\mathrm{B}_{0}$ ), samples with $2 \%$ (sample $\mathrm{B}_{2}$ ), $3 \%$ (sample $\mathrm{B}_{3}$ ) and $4 \%$ sand (sample $\mathrm{B}_{4}$ ) replaced with crumb rubber which yielded 30.71, 29.49, 25.31 and $23.97 \%$ oxygen contents respectively. Furthermore, crumb rubber has huge carbon content which reduces the strength and weakens the microstructure of concrete. The increment in the carbon content of concrete from 39.97 to 64.00 and $73.95 \%$ for the control sample (sample $\mathrm{B}_{0}$ ) to the concrete samples with $2 \%$ (sample $\mathrm{B}_{2}$ ) and $3 \%$ sand (sample $B_{3}$ ) replaced with crumb rubber, is suggestive of the rate of reduction in the strength and weakness in the microstructure of the concrete samples.

Materials with huge carbon content, such as crumb rubber, are chemically unreactive in the presence of heat or high temperature [35]. This can be responsible for the lack of compactness of carbon based materials, such as crumb rubber with loose or weak microstructure and reduced strength, when used in concrete $[36,37]$. The reduction in the strength and loose microstructure, especially when more than $1 \%$ sand is substituted with crumb rubber is established and becomes the emphasis of this work. This is comparable with literature [38], where enhancement of the microstructural and mechanical properties of $30 \mathrm{MPa}$ concrete were achieved with the substitution of small proportion of sand with crumb rubber; and also corroborates [31] that $0.5 \%$ cement and $0.5 \%$ sand can jointly be replaced with bentonite clay and crumb rubber in modified bentonite clay-crumb rubber concrete. 
Table 2. Elemental composition of concrete with sand partially substituted with crumb rubber by EDS

\begin{tabular}{|c|c|c|c|c|c|c|c|c|c|c|}
\hline \multirow[t]{2}{*}{ Elements } & \multicolumn{2}{|c|}{ Sample $\mathbf{B}_{0}$} & \multicolumn{2}{|c|}{ Sample $\mathbf{B}_{1}$} & \multicolumn{2}{|c|}{ Sample $\mathbf{B}_{2}$} & \multicolumn{2}{|c|}{ Sample $\mathbf{B}_{\mathbf{3}}$} & \multicolumn{2}{|c|}{ Sample $\mathbf{B}_{4}$} \\
\hline & Weight \% & Atomic \% & Weight \% & Atomic \% & Weight \% & Atomic \% & Weight $\%$ & Atomic \% & Weight $\%$ & Atomic $\%$ \\
\hline $\mathrm{C}$ & 39.97 & 54.70 & - & - & 64.00 & 72.22 & 73.95 & 79.29 & 4.00 & 8.77 \\
\hline $\mathrm{O}$ & 30.71 & 31.55 & 31.45 & 57.84 & 29.49 & 24.99 & 25.31 & 20.37 & 23.97 & 39.40 \\
\hline $\mathrm{Mg}$ & 0.35 & 0.24 & - & - & - & - & - & - & - & - \\
\hline $\mathrm{Al}$ & 1.20 & 0.73 & - & - & 0.54 & 0.27 & - & - & 3.74 & 3.65 \\
\hline $\mathrm{Si}$ & 6.11 & 3.57 & - & - & 0.96 & 0.46 & 0.75 & 0.34 & 11.83 & 11.07 \\
\hline $\mathrm{P}$ & 2.28 & 1.21 & - & - & 3.65 & 1.60 & - & - & - & - \\
\hline $\mathrm{Ca}$ & 17.71 & 7.26 & - & - & 1.36 & 0.46 & - & - & 52.79 & 34.64 \\
\hline $\mathrm{Fe}$ & - & - & 48.62 & 25.62 & - & - & - & - & - & - \\
\hline $\mathrm{K}$ & 0.70 & 0.29 & - & - & - & - & - & - & 3.67 & 2.47 \\
\hline $\mathrm{Cl}$ & 0.97 & 0.45 & 19.93 & 16.54 & - & - & - & - & - & - \\
\hline
\end{tabular}

\section{CONCLUSIONS}

The microstructural and mechanical properties of modified crumb rubber concrete have been investigated. The conclusions are as follow:

(1) The slump of the control concrete sample was $45 \mathrm{~mm}$ while those of samples with 1,2,3 and $4 \%$ sand substituted with crumb rubber ranged between 40 and $30 \mathrm{~mm}$. The use of crumb rubber did not affect the workability of concrete.

(2) The bulk density of the control and modified crumb rubber concrete samples ranged between 2300 and 2340 $\mathrm{kg} / \mathrm{m} 3$ and can all be classified as normal weight concrete

(3) Substitution of $1 \%$ sand with crumb rubber is the optimal proportion that can produce improved modified crumb rubber concrete.

(4) Substitution of $1 \%$ sand with crumb rubber is the optimal proportion that can produce the densest microstructure and improved strength of modified crumb rubber concrete.

(5) Substitution of $1 \%$ sand with crumb rubber can give mechanically improved and microstructurally enhanced modified crumb rubber concrete.

\section{ACKNOWLEDGMENT}

The Department of Civil Engineering and the Faculty of Engineering and the Built Environment, Tshwane University of Technology, Pretoria South Africa are acknowledged for sponsoring the lead author to attend Waste Management Conference 2018 in Seville, Spain.

\section{REFERENCES}

[1] Mohee, R., Simelane, T. (eds). (2015). Future Directions of Municipal Solid Waste Management in Africa. Africa Institute of South Africa.

[2] Kumaran, G.S., Mushule, N., Lakshmipathy, M. (2008). A review on construction technologies that enables environmental protection: Rubberized concrete. Am. J. Engg. \& Applied Sci., 1(1): 40-44. https://doi.org/10.3844/ajeassp.2008.40.44

[3] Najim, K.B., Hall, M.R. (2011). Thermo-physical and mechanical analysis of Self-Compacting Rubberised Concrete (SCRC) mix classes. Proceedings of the 13th International Conference on Non-conventional Materials and Technologies (13 NOCMAT 2011), Changsha, Hunan, China.
[4] Richardson, A., Coventry, K., Dave, U., Pienaar, J. (2011). Freeze/thaw performance of concrete using granulated rubber crumb. Journal of Green Building, 6(1): 83-92. https://doi.org/10.3992/jgb.6.1.83

[5] Meadows, D., Randers, J. (2012). The Limits to Growth: The 30-Year Update. Routledge.

[6] Grimm, N.B., Faeth, S.H., Golubiewski, N.E., Redman, C.L., Wu, J., Bai, X., Briggs, J.M. (2008). Global change and the ecology of cities. Science, 319(5864): 756-760. https://doi.org/10.1126/science.1150195

[7] Godfray, H.C.J., Beddington, J.R., Crute, I.R., Haddad, L., Lawrence, D., Muir, J.F., Pretty, J., Robinson, S., Thomas, S.M., Toulmin, C. (2010). Food security: The challenge of feeding 9 billion people. Science, 327(5967): 812-818. https://doi.org/10.1126/science. 1185383

[8] Paul, R. (2009). End-of-life management of waste automotive materials and efforts to improve sustainability in North America. WIT Transactions on Ecology and the Environment, 120: 853-861. https://doi.org/10.2495/SDP090802

[9] Saleh, T.A., Gupta, V.K. (2014). Processing methods, characteristics and adsorption behavior of tire derived carbons: a review. Advances in Colloid and Interface Science, 211: 93-101. https://doi.org/10.1016/j.cis.2014.06.006

[10] Plesuma, R., Megne, A., Mateusa-Krukle, I., Malers, L. (2013). Mechanical properties of the composite material based on modified scrap tires and polymer binder. Progress in Rubber, Plastics and Recycling Technology, 29(3): 177-187.

[11] Zhou, Y., Fan, M., Chen, L., Zhuang, J. (2015). Lignocellulosic fibre mediated rubber composites: an overview. Composites Part B: Engineering, 76: 180-191. https://doi.org/10.1016/j.compositesb.2015.02.028

[12] Butu, A.W., Mshelia, S.S. (2014). Municipal solid waste disposal and environmental issues in Kano metropolis, Nigeria. British Journal of Environmental Sciences, 2(1): $1-16$.

[13] Muzenda, E. (2014). A discussion on waste generation and management trends in South Africa. International Journal of Chemical, Enironmental \& Biological Sciences (IJCEBS), 2(2): 105-112.

[14] Aderinlewo, O.O. (2007). Risk analysis of a scrap tire embankment using influence diagrams. University of Delaware.

[15] Eckstein, B. (2012). From your car to your patio: using recycled tire products in building projects. Journal of Green Building, 7(3): 16-31. 
[16] Liang, T. (2013). Continuous devulcanization of ground tire rubber of different particle sizes using an ultrasonic twin-screw extruder. Doctoral Dissertation, University of Akron.

[17] Hazeri, S. (2017). Energy harvesting in pneumatic tires through piezoelectric material and its life cycle environmental impact. Doctoral Dissertation, Concordia University.

[18] Batayneh, M.K., Marie, I., Asi, I. (2008). Promoting the use of crumb rubber concrete in developing countries. Waste Management, 28(11): 2171-2176. https://doi.org/10.1016/j.wasman.2007.09.035

[19] El-Gammal, A., Abdel-Gawad, A.K., El-Sherbini, Y., Shalaby, A. (2010). Compressive strength of concrete utilizing waste tire rubber. Journal of Emerging Trends in Engineering and Applied Sciences, 1(1): 96-99.

[20] Youssf, O., Mills, J.E., Hassanli, R. (2016). Assessment of the mechanical performance of crumb rubber concrete. Construction and Building Materials, 125: 175-183. https://doi.org/10.1016/j.conbuildmat.2016.08.040

[21] Aravind, V.M., George, J., Jubeena, T.A., Basheer, S.M., James, S. (2017). Experimental investigation on Improvement of Rubcrete. International Journal of Innovative Research in Science, Engineering and Technology, 6(4): 5572-5576. https://doi.org/10.15680/IJIRSET.2017.060411

[22] SANS 50197-1, South African National Standard. Composition, Specifications and conformity criteria for common cements. Pretoria, South Africa, 2013.

[23] SANS 5862-1, South African National Standard. Concrete Tests - Consistence of Freshly mixed concrete - Slump Test. Pretoria, South Africa, 2006.

[24] EN 12390-7. Testing Hardened Concrete: Density of Hardened Concrete. European Standard. 2009.

[25] SANS 5863, South African National Standard. Concrete Tests-Compressive strength of hardened concrete. Pretoria, South Africa, 2006.

[26] SANS 6253, South African National Standard. Concrete Tests-Tensile splitting strength of concrete. Pretoria, South Africa, 2006.

[27] SANS 5861-1, South African National Standard. Concrete Tests - Mixing fresh concrete in the laboratory. Pretoria, South Africa, 2006.

[28] Owens, G. ed., Fulton's concrete technology. Cement \& Concrete Institute, 2009.
[29] Akinyele, J.O., Salim, R.W., Kupolati, W.K. (2016). Production of lightweight concrete from waste tire rubber crumb. Engineering Structures and Technologies, 8(3):

108-116. https://doi.org/10.3846/2029882X.2016.1209727

[30] Siva Kumar, T., Prabha, P., Bhuvaneshwari, B., Regupati, R. (2014). Characteristics of Functionally Modified Foamed Concrete by Nano-Silica. International Journal of Engineering Reach Technology, 3(5).

[31] Adeboje, A.O., Kupolati, W.K., Sadiku, E.R., Ndambuki, J.M., Kambole, C. (2019). Experimental investigation of modified bentonite clay-crumb rubber concrete. Construction and Building Materials, 233: 117187. http://dx.doi.org/10.1016/j.conbuildmat.2019.117187

[32] Owens, G. (Ed.). (2013). Fundamentals of Concrete. Cement and Concrete Institute, Midrand, South Africa.

[33] Zhang, L., Niu, J., Dai, L., Xia, Z. (2012). Effect of microstructure of nitrogen-doped graphene on oxygen reduction activity in fuel cells. Langmuir, 28(19): 75427550. https://doi.org/10.1021/la2043262

[34] Jonkers, H.M., Thijssen, A., Muyzer, G., Copuroglu, O., Schlangen, E. (2010). Application of bacteria as selfhealing agent for the development of sustainable concrete. Ecological Engineering, 36(2): 230-235. https://doi.org/10.1016/j.ecoleng.2008.12.036

[35] Khale, D., Chaudhary, R. (2007). Mechanism of geopolymerization and factors influencing its development: A review. Journal of Materials Science, 42(3): 729-746. https://doi.org/10.1007/s10853-0060401-4

[36] Sanchez, F., Sobolev, K. (2010). Nanotechnology in concrete-a review. Construction and Building Materials, 24(11): 2060-2071. https://doi.org/10.1016/j.conbuildmat.2010.03.014

[37] Shi, C., Zheng, K. (2007). A review on the use of waste glasses in the production of cement and concrete. Resources, conservation and recycling, 52(2): 234-247. https://doi.org/10.1016/j.resconrec.2007.01.013

[38] Adeboje, A.O., Kupolati, W.K., Sadiku, E.R., Ndambuki, J.M. (2019). Influence of partial substitution of sand with crumb rubber on the microstructural and mechanical properties of concrete in Pretoria, South Africa. International Journal of Environment and Waste Management, $24(1)$ 39-60. http://dx.doi.org/10.1504/IJEWM.2019.100657 